\title{
Friction and wear properties of quasi-periodic material coatings
}

\author{
C I LANG, D SHECHTMAN ${ }^{\dagger}$ and E GONZALEZ ${ }^{\dagger \dagger}$ \\ University of Cape Town, South Africa and NIST, Gaithersburg, Maryland \\ ${ }^{\dagger}$ Technion, Haifa, Israel and NIST, Gaithersburg, Maryland \\ ${ }^{+\dagger}$ NIST, Gaithersburg, Maryland
}

\begin{abstract}
Quasicrystalline (QC) materials are of interest not only because of their unique structure, but also because they exhibit unusual properties which are potentially useful in industrial applications. In the present study a range of aluminium-based QC alloys, in the form of plasma-sprayed coatings, has been produced and evaluated. For the first time the influence of heat treatment on the structure and properties of these coatings has been systematically investigated. Of the nine QC coatings investigated, those of the $\mathrm{Al}-\mathrm{Cu}-\mathrm{Fe}-\mathrm{Cr}$ system and the Al-Pd-Mn system showed the most promising combination of good hardness with low coefficient of friction.
\end{abstract}

Keywords. Friction; wear; quasi-periodic material.

\section{Introduction}

The discovery of quasiperiodic crystals (Shechtman et al 1984) in 1982 led to an unprecedented multidisciplinary effort to understand the unique structure of these materials, now commonly known as quasicrystals (QCs). In more recent years efforts have turned to measurement of the properties of QC materials, owing to the discovery of stable quasicrystals that can be produced in volumes suitable for experimental measurements. The next stage in the development of QCs, still in the future, will be the utilization of QC materials in industrial and commercial applications.

Unlike conventional metallic alloys, QC materials exhibit high hardness and stiffness, but low fracture toughness; and are reported to exhibit a very low coefficient of friction (e.g. Kang et al 1993). Their high hardness and low friction coefficients suggest that QC materials may be valuable in tribological applications. The utilization of QC materials in bulk form is compromised by their low fracture toughness, necessitating their use in combination with more ductile materials. This is of particular interest for tribological applications, in which the surface properties of QC materials (hardness and low friction coefficient) may be combined with the bulk properties of conventional metals (toughness and ductility) by means of a QC coating on a metallic substrate. In the present work a range of potentially useful QC materials is evaluated, with a view to identifying promising materials for tribological applications.

$\mathrm{Al}-\mathrm{Cu}-\mathrm{Fe}$ quasicrystalline materials have been the subject of extensive investigation since the first report

*Author for correspondence of a stable icosahedral phase, of composition $\mathrm{Al}_{65} \mathrm{Cu}_{20} \mathrm{Fe}_{15}$, in 1987 (Tsai et al 1987). A related family of $\mathrm{Al}-\mathrm{Cu}-$ $\mathrm{Fe}-\mathrm{Cr} \mathrm{QC}$ alloys has been obtained by the addition of chromium, which decreases the stability of the icosahedral phase and promotes the formation of a decagonal phase (Dong and Dubois 1991). In the $\mathrm{Al}-\mathrm{Cu}-\mathrm{Fe}$ system and in the $\mathrm{Al}-\mathrm{Co}-\mathrm{Fe}-\mathrm{Cr}$ system, quasicrystalline approximant phases are also observed (Dubois and Pianelli 1995). Other cobalt-containing QCs include $\mathrm{Al}_{70} \mathrm{Co}_{15} \mathrm{Ni}_{15}$, for which a stable decagonal phase was reported in 1989 (Tsai et al 1989). In 1990 another thermodynamically stable QC alloy with an icosahedral structure and a composition $\mathrm{Al}_{70} \mathrm{Pd}_{20} \mathrm{Mn}_{10}$ was reported (Tsai et al 1990); this structure is reported to be more ordered than the $\mathrm{Al}_{65} \mathrm{Cu}_{20} \mathrm{Fe}_{15} \mathrm{QC}$ alloy (Tsai et al 1991). Representative QCs from the above groups are therefore expected to exhibit icosahedral, decagonal or approximant phases, or the combinations thereof.

\section{Experimental}

Seven aluminium-based QC alloy compositions were selected for production of coatings (table 1). The first five starting powders listed in table 1 are available commercially. Powders of composition $\mathrm{Al}_{70.9} \mathrm{Cu}_{9} \mathrm{Fe}_{10} \mathrm{Cr}_{10} \mathrm{~B}_{0.1}$ and $\mathrm{Al}_{70} \mathrm{Pd}_{20} \mathrm{Mn}_{10}$ were produced specifically for this study by gas atomization.

Coatings were produced by a plasma spray process, from the seven starting powders listed in table 1 and also from $\mathrm{Al}_{65} \mathrm{Cu}_{23} \mathrm{Fe}_{12}$ and $\mathrm{Al}_{70} \mathrm{Pd}_{20} \mathrm{Mn}_{10}$ powders to which $1 \mathrm{wt} \%$ FeAl had been added. Coatings were typically $0.5 \mathrm{~mm}$ thick and adhered well to metallic substrates. The QC coatings were evaluated in the as-sprayed condition as well as after heat treatment, $500^{\circ} \mathrm{C}-800^{\circ} \mathrm{C}$. 
Heat treatments were carried out under vacuum for $16 \mathrm{~h}$ followed by slow cooling. Compositional and crystallographic data were acquired by energy dispersive spectroscopy (EDS), X-ray diffraction (XRD) using $\mathrm{CuK} \alpha$ radiation, and electron diffraction. Hardness was evaluated by microhardness measurements using a Vickers indenter and a $25 \mathrm{~g}$ load. The coefficient of friction was determined using a pin-on-disc apparatus: friction was measured during sliding against a $0.79 \mathrm{~mm}$ diameter steel ball counterface, under a load of $2 \mathrm{~N}$, at a linear velocity of $1 \mathrm{~cm} \mathrm{~s}^{-1}$. Thermal diffusivity was measured by a photothermal reflection technique.

\section{Results}

The evolution of phase structure with heat treatment, $500^{\circ} \mathrm{C}-800^{\circ} \mathrm{C}$, is shown in table 2 . In the as-sprayed condition, only the $\mathrm{Al}_{70} \mathrm{Co}_{15} \mathrm{Ni}_{15}$ exhibited a single-phase structure. All the other coatings exhibited more than one phase, typically a $\mathrm{QC}$ phase in association with a periodic phase. QC phases are observed consistently in all the coatings after all heat treatments. In general, the effect of heat treatment is only to change the relative volume fraction of the phases present. An exception is the

Table 1. QC powder compositions selected for this study.

QC powder compositions

$$
\begin{aligned}
& \mathrm{Al}_{65} \mathrm{Cu}_{23} \mathrm{Fe}_{12} \\
& \mathrm{Al}_{67} \mathrm{Cu}_{10} \mathrm{Fe}_{10} \mathrm{Cr}_{10} \mathrm{Si}_{3} \\
& \mathrm{Al}_{71} \mathrm{Co}_{13} \mathrm{Fe}_{8} \mathrm{Cr}_{8} \\
& \mathrm{Al}_{70} \mathrm{Co}_{10} \mathrm{Fe}_{13} \mathrm{Cr}_{7} \mathrm{Hf}_{0.4} \\
& \mathrm{Al}_{70} \mathrm{Co}_{15} \mathrm{Ni}_{15} \\
& \mathrm{Al}_{70.9} \mathrm{Cu}_{9} \mathrm{Fe}_{10} \mathrm{Cr}_{10} \mathrm{~B}_{0.1} \\
& \mathrm{Al}_{70} \mathrm{Pd}_{20} \mathrm{Mn}_{10} \\
& \hline
\end{aligned}
$$

$\mathrm{Al}-\mathrm{Cu}-\mathrm{Fe}-\mathrm{Cr}$ QC coatings, $\left(\mathrm{Al}_{70.9} \mathrm{Cu}_{9} \mathrm{Fe}_{10} \mathrm{Cr}_{10} \mathrm{~B}_{0.1}\right.$ and $\mathrm{Al}_{67} \mathrm{Cu}_{10} \mathrm{Fe}_{10} \mathrm{Cr}_{10} \mathrm{Si}_{3}$ ), in which heat treatment results in the disappearance of the icosahedral phase.

Heat treatment is seen to result in an increase in the volume fraction of icosahedral phase only for the $\mathrm{QC}$ coatings of $\mathrm{Al}-\mathrm{Cu}-\mathrm{Fe},\left(\mathrm{Al}_{65} \mathrm{Cu}_{23} \mathrm{Fe}_{12}\right.$ and $\mathrm{Al}_{65} \mathrm{Cu}_{23} \mathrm{Fe}_{12}$ $+1 \mathrm{wt} \% \mathrm{FeAl}$ ). For QC coatings which contain both icosahedral and decagonal phases in the as-cast condition, heat treatment results in an increase in the volume fraction of the decagonal phase. Figure 1 shows the influence of heat treatment on the thermal diffusivity of the QC coating of $\mathrm{Al}_{65} \mathrm{Cu}_{23} \mathrm{Fe}_{12}$ (for which heat treatment results in a rapid increase in the icosahedral phase) and the $\mathrm{QC}$ coating of $\mathrm{Al}_{70} \mathrm{Pd}_{20} \mathrm{Mn}_{10}$ (for which heat treatment results in a decrease in the icosahedral phase). Thermal diffusivity is observed to decrease as the amount of icosahedral phase increases, and vice versa.

The hardness of the $\mathrm{QC}$ coatings is shown in figure 2 . The multiphase structure of the coatings together with microcracking and porosity, result in a wide scatter of hardness measurements as seen from the error bars (plus

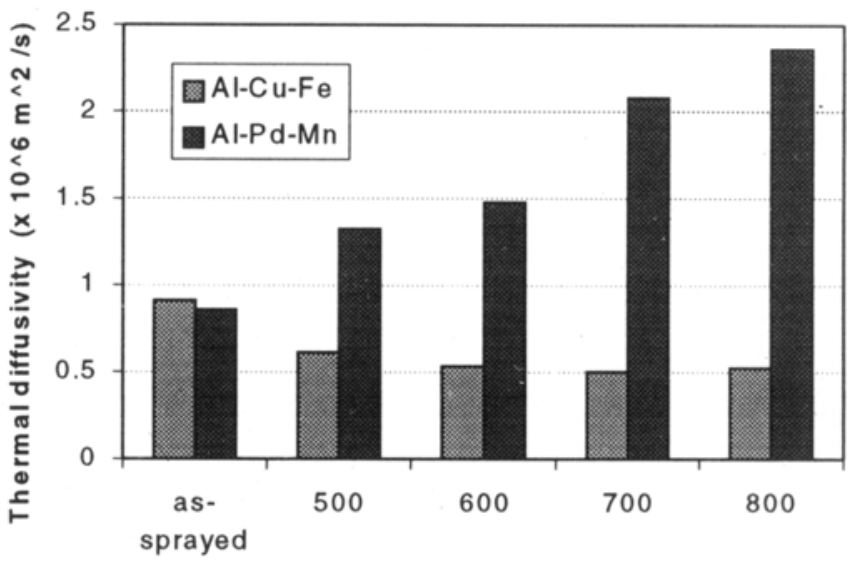

Heat treatment temperature

Figure 1. Thermal diffusivity of the $\mathrm{QC}$ coatings of $\mathrm{Al}_{65} \mathrm{Cu}_{23} \mathrm{Fe}_{12}$ and $\mathrm{Al}_{70} \mathrm{Pd}_{20} \mathrm{Mn}_{10}$.

Table 2. Phase structure of QC coatings: $\Psi$, icosahedral phase; D, decagonal phase; A, approximant phase; P, periodic phase.

\begin{tabular}{lll}
\hline QC coating & as-sprayed & $\begin{array}{l}\text { After heat treatment } \\
\left(500^{\circ} \mathrm{C}-800^{\circ} \mathrm{C}\right)\end{array}$ \\
\hline $\mathrm{Al}_{65} \mathrm{Cu}_{23} \mathrm{Fe}_{12}$ & $\mathrm{P}+\Psi$ & $\rightarrow \Psi+\mathrm{P}$ \\
$\mathrm{Al}_{65} \mathrm{Cu}_{23} \mathrm{Fe}_{12}+1 \mathrm{wt} \% \mathrm{FeAl}$ & $\mathrm{P}+\Psi$ & $\rightarrow \Psi+\mathrm{P}$ \\
$\mathrm{Al}_{709} \mathrm{Cu}_{9} \mathrm{Fe}_{10} \mathrm{Cr}_{10} \mathrm{~B}_{0.1}$ & $\Psi+\mathrm{P}+\mathrm{D}$ & $\rightarrow \mathrm{D} \rightarrow \mathrm{D}+\mathrm{P}$ \\
$\mathrm{Al}_{67} \mathrm{Cu}_{10} \mathrm{Fe}_{10} \mathrm{Cr}_{10} \mathrm{Si}_{3}$ & $\Psi+\mathrm{D}$ & $\rightarrow \mathrm{D}+\Psi \rightarrow \mathrm{D}$ \\
$\mathrm{Al}_{71} \mathrm{Co}_{13} \mathrm{Fe}_{8} \mathrm{Cr}_{8}$ & $\mathrm{~A}+\mathrm{P}$ & $\mathrm{A}+\mathrm{P}$ \\
$\mathrm{Al}_{70} \mathrm{Co}_{10} \mathrm{Fe}_{13} \mathrm{Cr}_{7} \mathrm{Hf}_{0.4}$ & $\mathrm{~A}+\mathrm{P}$ & $\mathrm{A}+\mathrm{P}$ \\
$\mathrm{Al}_{70} \mathrm{Co}_{15} \mathrm{Ni}_{15}$ & $\mathrm{D}$ & $\rightarrow \mathrm{D}+\mathrm{P}$ \\
$\mathrm{Al}_{70} \mathrm{Pd}_{20} \mathrm{Mn}_{10}$ & $\Psi+\mathrm{D}+\mathrm{P}$ & $\rightarrow \mathrm{D}+\Psi+\mathrm{P} \rightarrow \mathrm{D}+\mathrm{P}+\Psi$ \\
$\mathrm{Al}_{70} \mathrm{Pd}_{20} \mathrm{Mn}_{10}+1 \mathrm{wt} \% \mathrm{FeAl}$ & $\Psi+\mathrm{D}+\mathrm{P}$ & $\rightarrow \mathrm{D}+\Psi+\mathrm{P} \rightarrow \mathrm{D}+\mathrm{P}+\Psi$ \\
\hline
\end{tabular}


and minus standard deviation). Some compositional dependence is also observed: the cobalt-containing coatings $\left(\mathrm{Al}_{71} \mathrm{Co}_{13} \mathrm{Fe}_{8} \mathrm{Cr}_{8}, \quad \mathrm{Al}_{70} \mathrm{Co}_{10} \mathrm{Fe}_{13} \mathrm{Cr}_{7} \mathrm{Hf}_{0.4}\right.$ and $\mathrm{Al}_{70} \mathrm{Co}_{15} \mathrm{Ni}_{15}$ ) consistently exhibit high hardness. No systematic variation in hardness is observed as a result of heat treatment or phase changes.

The friction coefficient of QC coatings in the as-sprayed and heat-treated conditions is shown in figure 3. A great variation in coefficient of friction is observed. High coefficients of friction are exhibited by the cobaltcontaining QC coatings (notably $\mathrm{Al}_{70} \mathrm{Co}_{10} \mathrm{Fe}_{13} \mathrm{Cr}_{7} \mathrm{Hf}_{0,4}$ and $\mathrm{Al}_{70} \mathrm{Co}_{15} \mathrm{Ni}_{15}$ ) and by the chromium-containing coatings $\left(\mathrm{Al}_{67} \mathrm{Cu}_{10} \mathrm{Fe}_{10} \mathrm{Cr}_{10} \mathrm{Si}_{3}\right.$ and $\left.\mathrm{Al}_{70.9} \mathrm{Cu}_{9} \mathrm{Fe}_{10} \mathrm{Cr}_{10} \mathrm{~B}_{0.1}\right)$. Considering only the as-sprayed condition, the $\mathrm{QC}$ coatings of $\mathrm{Al}_{65} \mathrm{Cu}_{23} \mathrm{Fe}_{12}$ show the lowest coefficient of friction, followed by the $\mathrm{QC}$ coatings of $\mathrm{Al}_{70} \mathrm{Pd}_{20} \mathrm{Mn}_{10}$. In general, heat treatment reduces the coefficient of friction. For instance, the friction coefficient of the $\mathrm{QC}$ coatings of $\mathrm{Al}_{70} \mathrm{Pd}_{20} \mathrm{Mn}_{10}$ is reduced considerably after heat treatment. The most dramatic change is seen in the heat treatment, $800^{\circ} \mathrm{C}$, of $\mathrm{QC}$ coating of $\mathrm{Al}_{70,4} \mathrm{Cu}_{3} \mathrm{Fe}_{10} \mathrm{Cr}_{10} \mathrm{~B}_{0,1}$ which results in a decrease in friction coefficient from nearly 0.6 to an exceptionally low value of 0.15 .

\section{Discussion}

The breadth of this study has enabled a preliminary evaluation to be made of the structural influences on the properties of interest. Thermal diffusivity is clearly sensitive to the volume fraction of icosahedral phase. This is to be expected, since low thermal (and electrical) conductivity is characteristic of the quasicrystalline state. The conductivity of decagonal quasicrystals is low in the quasicrystalline plane but high in the periodic direction; polycrystalline decagonal QC materials are therefore expected to exhibit a higher thermal diffusivity than icosahedral QC materials. This is illustrated in figure 1,

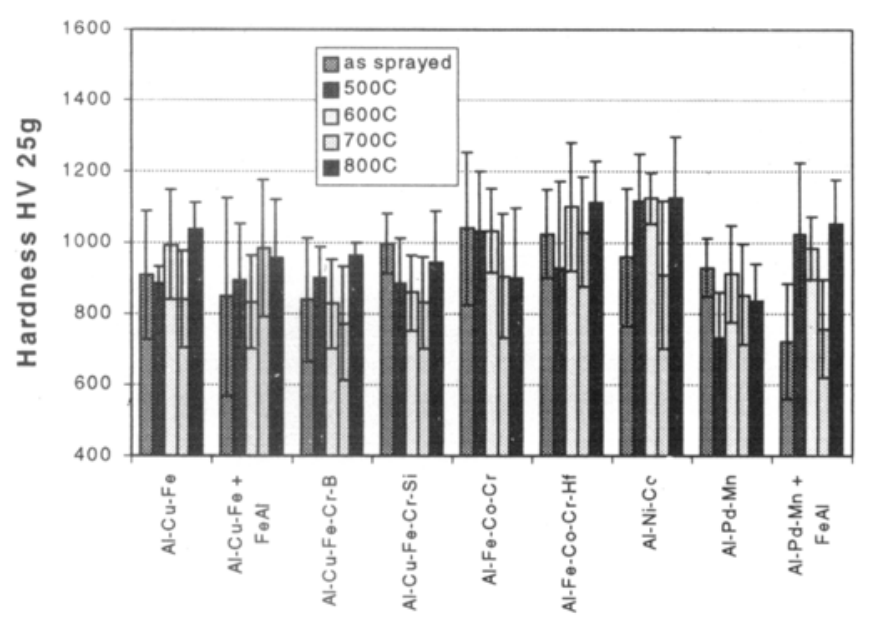

Figure 2. Hardness of as-sprayed and heat-treated QC coatings. which shows that although the diffusivity of (partially icosahedral) $\mathrm{QC}$ coatings of $\mathrm{Al}_{65} \mathrm{Cu}_{23} \mathrm{Fe}_{12}$ and $\mathrm{Al}_{70} \mathrm{Pd}_{20} \mathrm{Mn}_{10}$ is similar in the as-sprayed condition, after heat treatment the diffusivity of these two coatings differs significantly. After heat treatment, the increasing predominance of the decagonal phase in the $\mathrm{QC}$ coating of $\mathrm{Al}_{70} \mathrm{Pd}_{20} \mathrm{Mn}_{10}$ results in an increase in diffusivity whereas the increasing predominance of the icosahedral phase in the QC coating of $\mathrm{Al}_{65} \mathrm{Cu}_{23} \mathrm{Fe}_{12}$ results in a decrease.

Hardness appears to be more sensitive to composition than phase structure, with the cobalt-containing QC coatings exhibiting high hardness. Friction coefficient is influenced by both phase structure and composition. The lowest friction coefficient values (below 0.25) are all obtained from predominantly decagonal QC coatings; in the $\mathrm{QC}$ coatings of $\mathrm{Al}-\mathrm{Cu}-\mathrm{Fe}-\mathrm{Cr}$ and $\mathrm{Al}-\mathrm{Pd}-\mathrm{Mn}$ a transformation from a predominantly icosahedral to a predominantly decagonal structure is accompanied by a significant decrease in friction coefficient. However, an increase in icosahedral phase in the $\mathrm{QC}$ coatings of $\mathrm{Al}_{65} \mathrm{Cu}_{23} \mathrm{Fe}_{12}$ is also accompanied by a decrease in friction coefficient; and the decagonal QC coating of $\mathrm{Al}_{70} \mathrm{Co}_{15} \mathrm{Ni}_{15}$ exhibits a very high friction coefficient, decreasing with the appearance of a periodic phase. These results suggest a complex dependence of friction coefficient on both composition and structure.

The high hardness of the cobalt-containing QC coatings suggests that they may be useful in tribological applications: however, the friction coefficients exhibited by these coatings are disappointingly high. The best combination of good hardness and low coefficient of friction is exhibited by the $\mathrm{Al}_{70.9} \mathrm{Cu}_{9} \mathrm{Fe}_{10} \mathrm{Cr}_{10} \mathrm{~B}_{0.1}$ and $\mathrm{Al}_{70} \mathrm{Pd}_{20} \mathrm{Mn}_{10}+1 \mathrm{wt} \% \mathrm{FeAl} \mathrm{QC}$ coatings, in each case after heat treatment at $800^{\circ} \mathrm{C}$. The hardness of the $\mathrm{QC}$

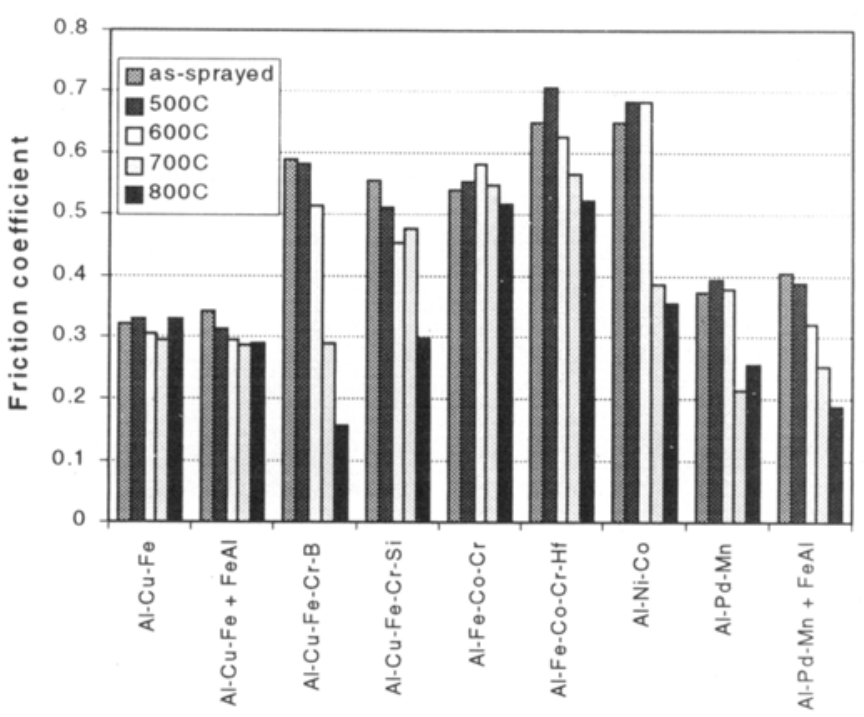

Figure 3. Friction coefficients of as-sprayed and heat-treated QC coatings. 
coating $\mathrm{Al}_{70.9} \mathrm{Cu}_{9} \mathrm{Fe}_{10} \mathrm{Cr}_{10} \mathrm{~B}_{0.1}$ is consistent with the hardness of the other $\mathrm{Al}-\mathrm{Cu}-\mathrm{Fe}$ based coatings; the hardness of the $\mathrm{Al}_{70} \mathrm{Pd}_{20} \mathrm{Mn}_{10}+1$ wt\% $\mathrm{FeAl}$ coating of $\mathrm{QC}$ is however greater than that of the $\mathrm{QC}$ coating of $\mathrm{Al}_{70} \mathrm{Pd}_{20} \mathrm{Mn}_{10}$ suggesting that the addition of $1 \mathrm{wt} \% \mathrm{FeAl}$ confers improved hardness on this alloy. As noted above for low-friction coatings, both the $\mathrm{Al}_{70.9} \mathrm{Cu}_{9} \mathrm{Fe}_{101} \mathrm{Cr}_{10} \mathrm{~B}_{0,1}$ and $\mathrm{Al}_{70} \mathrm{Pd}_{20} \mathrm{Mn}_{10}$ coatings of $\mathrm{QC}$ contain a decagonal phase, with a periodic phase (the $\mathrm{Al}_{70} \mathrm{Pd}_{20} \mathrm{Mn}_{10}+1 \mathrm{wt} \%$ FeAl coating of $\mathrm{QC}$ contains, in addition, a small volume fraction of icosahedral phase).

Thus, sprayed coatings of high hardness and low coefficient of friction can be produced from quasicrystalline alloys. However, if these properties are to be optimized for applications, such as tribology, an understanding of the structure/property relationships within quasicrystalline alloy systems is necessary.

\section{Acknowledgements}

We wish to acknowledge DARPA and USAF for spon- soring this study. We appreciate the help we have received from Dan Sordelet and Matt Besser of Ames Laboratories, as well as Frank Biancaniello and Lew Ives, NIST.

\section{References}

Dong C and Dubois J M 1991 J. Mater. Sci. 261647

Dubois J M and Pianelli A 1995 US Patent no. 5,432,011

Kang S S, Dubois J M and von Stebut J 1993 J. Mater. Res. 82471

Shechtman D, Blech I, Gratias D and Cahn J W 1984 Phys. Rev. Lett. 531951

Tsai A P, Inoue A and Masumoto T $1987 \mathrm{Jpn}$. J. Appl. Phys. $29 \mathrm{~L} 1505$

Tsai A P, Inoue A and Masumoto T 1989 Mater. Trans. JIM 30150,463

Tsai A P, Inoue A, Yokayama Y and Masumoto T 1990 Mater. Trans. JIM 3198

Tsai A P, Chen H S, Inoue A and Masumoto T 1991 Phys. Rev. $\mathbf{B 4 3} 8782$ 